\title{
Experimental studies of benthos resistance to mechanical burying under the dredging material
}

\author{
Alexander Chusov ${ }^{1}$, Mikhail Shilin", ${ }^{2,}$, George Gogoberidze ${ }^{3}$, Julia Lednova $^{1}$, and Nikolai \\ Bobylev $^{2}$ \\ ${ }^{1}$ Peter the Great Polytechnical University, Polytechnicheskaya str., 29, 195251, St. Petersburg, Russia \\ ${ }^{2}$ St. Petersburg State University, Universitetskaya Emb., 7-9, 199034, St. Petersburg, Russia \\ ${ }^{3}$ Murmansk Arctic State University, Kapitana Egorova str., 15, 183038, Murmansk, Russia
}

\begin{abstract}
The goal of the fulfilled research is the study of the influence of the sedimentary suspension from the dredging material on the benthic hydrobionts. In laboratory aquariums six series of experiments were carried out with triple replication on the ability of different benthic organisms to dig out the soil strata due to their periodic burying by marine sand. These experiments were oriented on biota of Eastern Gulf of Finland and the Neva Bay, where a number of deposit sites for dredging material are located presently. Representatives of three main groups of hydrobionts of these areas were selected for experiments - Chironomidae, Gastropoda and Oligochaeta. The ability of different hydrobiont species to overcome the stress effect of the burying under the dredged material was estimated quantitatively. The results show, that the resistance of the studied species to mechanical burying is decreasing in accordance to the scheme: Chironomus plumosus $>$ Melanoides tuberculata $>$ Tubifex tubifex, and depends from the thickness of the layer of dredged material.
\end{abstract}

\section{Introduction}

Burying under a sedimentary suspension of dredging material is the main type of impact on benthic communities in dumping areas and on the sites of dredged material deposits [1-6]. It is of great scientific and practical importance to estimate quantitatively the ability of individual benthic species and the bottom community as a whole to overcome this kind of anthropogenic stress. Laboratory experiments on the effects of benthos overlapping with dredging material allow quantify the endurance limits of individual hydrobiont species and bottom communities in general to this type of anthropogenic impact. A series of laboratory experiments provided quantitative data on the stability of benthos to dumping. The resulting data can be used in planning the placement of dredging material to calculate the maximum allowable load on the natural environment, for the terms and conditions of Eastern Gulf of Finland (EGoF) and Neva Bay.

\section{Materials and Methods}

\footnotetext{
*Corresponding author: shilinspb@gmail.ru
} 
In vitro experiments were conducted on the ability of benthic organisms to dig out the soil strata due to their periodic burying in process of dumping. Three most abundant groups of benthic communities of EGoF and Neva Bay were selected [1-7]. There were Chironomidae «bloodworms» Chironomus plumosus, Gastropoda mollusks (marine snails) Melanoides tuberculate, and Oligochaete Tubifex tubifex. All selected objects can be observed as a model of the freshwater component of the EGoF fauna [7-10, 12]. The fauna of the Neva Bay is of the freshwater type $[9,10]$.

The sand was brought from the northern coast of the EGoF. Before the experiments, sand was ignited and sieved through sieves set with different cells for obtaining grain size less than $0.25 \mathrm{~mm}$.

Clear freshwater was used for filling aquariums with the hydrobionts. Before the experiment, water was exposed in the tank for two days for cleaning from chlorine.

The aquarium $(35 \times 10 \times 25 \mathrm{~cm})$ was filled by sand, $2 \mathrm{~cm}$ sick layer, and after that, the clean water was filled to the aquarium till $10 \mathrm{sm}$.

There were six series of experiments with triple replication. Every series included experiment on one type of organisms, with one quantity of sand, which means:

1) filling of Ch. plumosus every 3 hours with $1 \mathrm{~cm}$ sand layer;

2) filling of Ch. plumosus every 4 hours with $2 \mathrm{~cm}$ sand layer;

3 ) filling of $M$. tuberculata every 3 hours with $1 \mathrm{~cm}$ sand layer;

4) filling of $M$. tuberculata every 4 hours with $2 \mathrm{~cm}$ sand layer;

5) filling of T. tubifex every 3 hours with $1 \mathrm{~cm}$ sand layer;

6) filling of T. tubifex every 4 hours with $2 \mathrm{~cm}$ sand layer.

Every replication was made during one day. The base of methodology was passed an assumption that the hopper dredger loaded dredged material in underwater deposit site three times in a day.

\section{Results}

The problem of prediction of dredging and dumping influence on benthic communities is important for sustainable development of deposit sites regions and adjacent waters $[5,11$ 14]. Laboratory tests with different types of organisms were carried out, and this data was used for estimation of dredging works influence on benthic communities. Three types of organisms were used as testing objects: Chironomidae (Ch. plumosus), Gastropoda mollusks (M. tuberculata) and Oligochaete (T. tubifex). Results of experience are shown on the figures 1-8. On the axis « $\mathrm{x}$ » the time of experiment is shown; on the axis «y» - the number of organisms on the sand surface. The number of tested individuals of different species varied in different series from 10 to 30 .

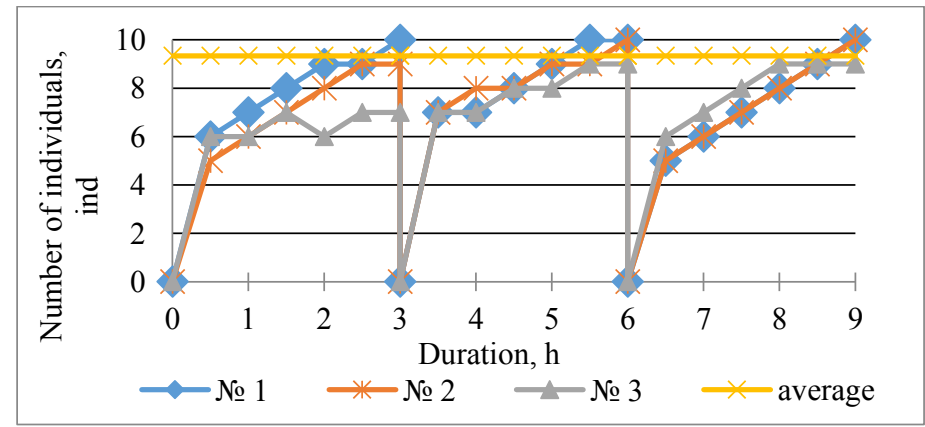

Fig. 1. Filling of Ch. plumosus every 3 hours with $1 \mathrm{~cm}$ sand layer 


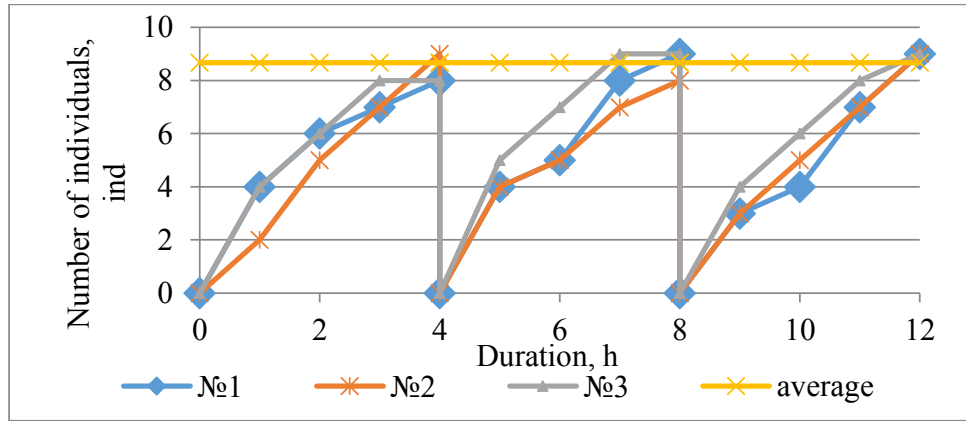

Fig. 2. Filling of Ch. plumosus every 4 hours with $2 \mathrm{~cm}$ sand layer

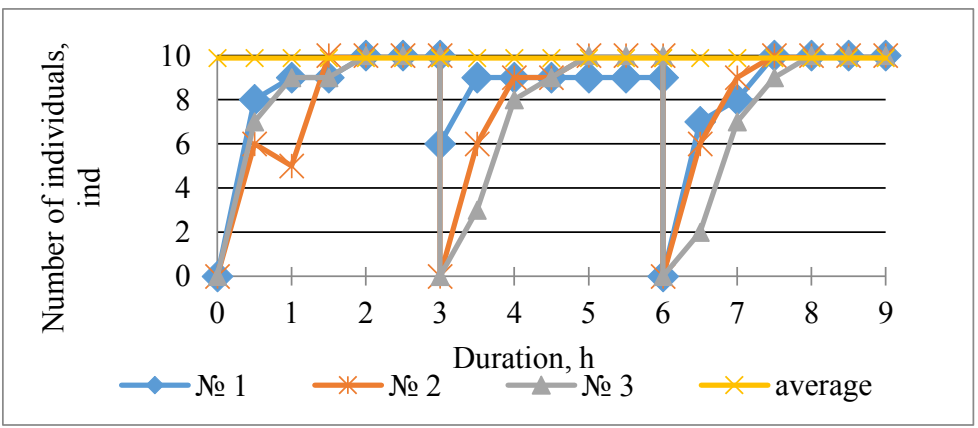

Fig. 3. Filling of M. tuberculata every 3 hours with $1 \mathrm{~cm}$ sand layer

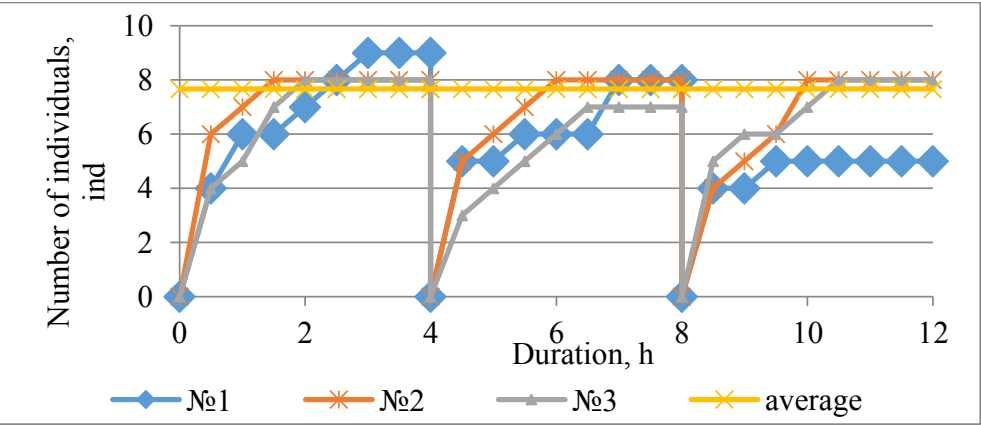

Fig. 4. Filling of M. tuberculata every 4 hours with $2 \mathrm{~cm}$ sand layer

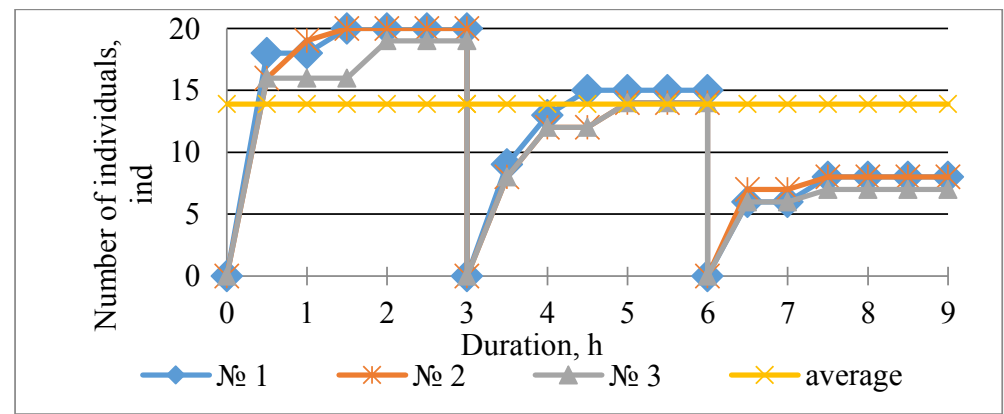

Fig. 5. Filling of T. tubifex every 3 hours with $1 \mathrm{~cm}$ sand layer 




Fig. 6. Filling of T. tubifex every 4 hours with $2 \mathrm{~cm}$ sand layer

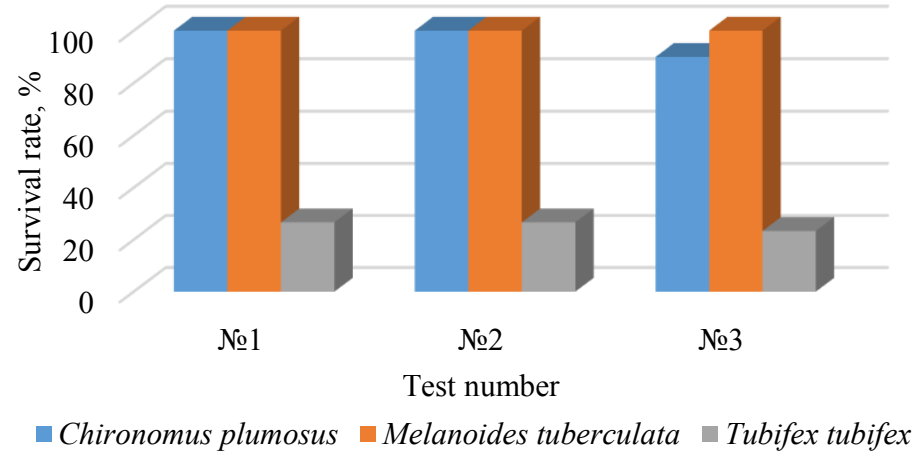

Fig. 7. Summary diagram of survival rate of Ch. plumosus, M. tuberculata and T. tubifex covered by $1 \mathrm{~cm}$ sand layer

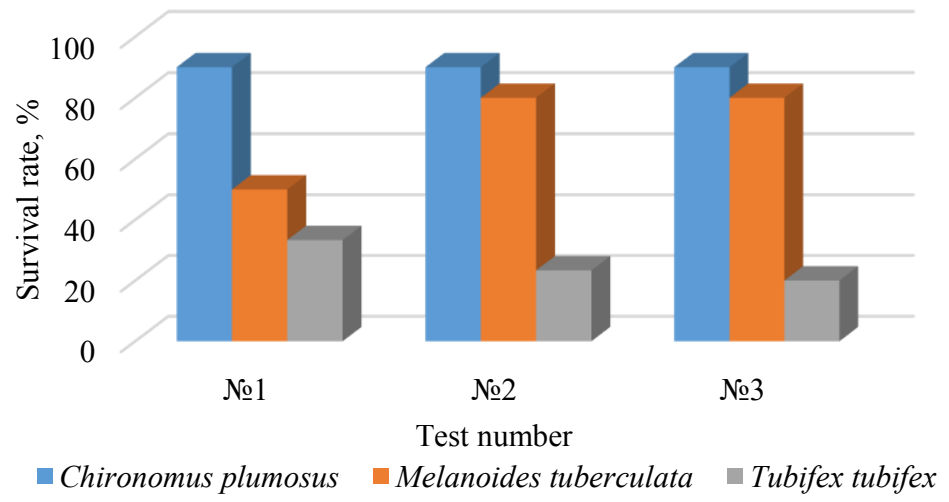

Fig. 8. Summary diagram of survival rate of Ch. plumosus, M. tuberculata and T. tubifex covered by $2 \mathrm{~cm}$ sand layer

Fig. 1 shows the relationship between the survival rate of bloodworms when covered with sand every 3 hours with a sand layer thickness of $1 \mathrm{~cm}$. The $\mathrm{x}$-axis indicates the time from the beginning of the experiment. The y-axis shows the number of bloodworms that have come to the surface through the layer of the sand. At the beginning of the experiment, 
10 individuals of bloodworms were put in a container with water and covered with $1 \mathrm{~cm}$ of sand. The sand covered $100 \%$ of the bloodworm individuals, so at the beginning of the experiment, the number of individuals on the sand surface was zero, and the graph starts from the beginning of the axis. Every hour, the presence of bloodworms on the surface was noted, as well as the presence of active bloodworms in the upper $0.5 \mathrm{~cm}$ surface layer, due to the fact that individuals of this species can burrow into the sand or into other soft soil.

After three hours from the beginning of the experiment, the total number of bloodworms on the surface of the sand and in the upper $0.5 \mathrm{~cm}$ was calculated. After that, $1 \mathrm{~cm}$ of sand was poured into a container, what is reflected in the graph by reducing the number of bloodworms on the surface of the sand to « 0 ».

The third time the sand was filled in 3 hours after the second filling, or 6 hours after the start of the experiment. After that, the observation of the number of bloodworms on the surface and the upper $0.5 \mathrm{~cm}$ layer of sand lasted 3 hours. Thus, the total duration of the experiment was 9 hours.

The appearance of bloodworms on the surface between the sand overlapping was unevenly, decreasing or increasing both over time and during the repetition of the experiment.

As can be seen from the Fig. 1, within 1 hour after the beginning of the experiment, at least 5 individuals out of 10 appeared on the surface of the sand (50\% survived organisms), and in the next two hours the rest of the individuals appeared (100\% survived organisms).

Fig. 2 shows the relationship between the survival of bloodworms after covering with sand every 4 hours, with $2 \mathrm{~cm}$ thick layer. The $\mathrm{x}$-axis indicates the time of the start and duration of the experiment. When sand layer was $2 \mathrm{~cm}$ thick, the amount of the bloodworms which appeared on the surface in the first hour of the experiment was 23 individuals on average (20-30\% of total number), in each of the three repetitions, and one hour after repeated covering with the sand. No more than $90 \%$ of individuals appeared on the surface of the sand finally.

Fig. 3 shows the number of snails M. tuberculata appeared on the surface, when $1 \mathrm{~cm}$ layer of sand covered them every 3 hours. The overall thickness of sand layer increased to $3 \mathrm{~cm}$ by the end of the experiment. The conditions of the experiment were similar to schedules 1 and 2 . The number of snails appeared on the surface in 30 minutes after the first overlap with the ground was at least 6 individuals, making a maximum of 8 individuals for three repetitions of the experiment. Number of individuals appearing on the surface at the second overlap by the ground after 30 minutes ranged from 3 to 6 , reaching 7-9 individuals by the end of the $1^{\text {st }}$ overlapping. After the third overlapping in different repetitions, the number of individuals who came to the surface varied significantly, but by the end of the experiment $100 \%$ of snails appeared on the surface.

Fig. 4 shows the relationship between the survival of $M$. tuberculata and the amount of sand covered the bottom of the aquarium. In this experiment, the sand was covered the aquarium's bottom with a layer $2 \mathrm{~cm}$ thick, with a frequency of every 4 hours. The total duration of the experiment was 12 hours. The differences between the experiments presented in Fig. 3 and Fig. 4 could be explained by different thickness of the sand layer ( 1 or $2 \mathrm{~cm}$ ) and the frequency of filling ( 3 and 4 hours, respectively).

The number of $M$. tuberculate individuals appearing on the surface in the first hour of the experiment was at least 5 for three repetitions (50\% survived organisms). At the end of four hours before refilling and at the end of the experiment, the number of individuals on the surface was no more than 9, while the minimum number of individuals was 5 . The average number of individuals appearing on the surface before each re-falling and at the end of the experiment was 8 specimens ( $80 \%$ of the total number).

Fig. 5 shows the relationship between the number of surviving individuals of the Oligochaets when covered with $1 \mathrm{~cm}$ sand layer with a frequency of 3 hours. The total 
duration of the experiment was 9 hours. At the beginning of the experiment, 30 individuals of $T$. tubifex were covered in the aquarium by $1 \mathrm{~cm}$ sand layer. After 1 hour of the experiment, in all three repetitions, the number of individuals on the surface was 16-19 individuals. After the second covering by sand, the maximum number of individuals was no more than 15. At the end of the experiment in all three repetitions the number of individuals was no more than 9 individuals.

Fig. 6 shows the relationship between the number of surviving Oligochaetes when covered with $2 \mathrm{~cm}$ sand layer with a frequency of 4 hours. The total duration of the experiment was 12 hours. The differences between the experiments presented in Fig. 5 and Fig. 6 could be explained by different thickness of the sand layer, overlapping the bottom of the aquarium ( 1 or $2 \mathrm{~cm}$ ), and the frequency of filling ( 3 or 4 hours, respectively). In the first hour of the experiment, the number of individuals on the surface was no more than 8 (from 30) in all series. The number of individuals on the surface before refilling and by the end of the experiment was more than 14 (from 30), however, the surviving individuals usually did not exceed 10 . The average number of individuals on the surface averaged 9 specimens (from 30).

Fig. 7 shows the correlation between the percentage of survivors for each type of test objects for each repetition when covered with a $1 \mathrm{~cm}$ sand layer with a frequency of covering 1 time every 3 hours. As can be seen from the graph, the largest number of survivors was observed by bloodworm and M. tuberculate, amounting to 90-100\%, while the survival of the Oligochaetes was no more than $30 \%$.

Fig. 8 shows the correlation between the percentage of survivors for each type of test object for each repetition when covered with a $2 \mathrm{~cm}$ sand layer with a frequency of covering falling 1 time every 4 hours. The highest percentage of survivors was found by bloodworm, amounting to $90 \%$. The lowest rates were observed by Oligochaetes, amounting to no more than $20 \%$.

\section{Conclusions}

To assess the impact of the effect of falling of the benthic communities by ground, a series of laboratory tests was carried out. The studies have found, that in the areas of deposit sites the status of benthic ecosystems strongly depends from the thickness of the layer which covers the organisms, and from the time intervals between dumpings from the hopper dredger. With increase of sand layer for a few centimeters per one day, some types of organisms, such as Chironomids, are better able to overcome this layer than other species of hydrobionts.

Thus, the most resistant to dig out from filling dumping material is the bloodworm Ch. plumosus. A survival scheme could be shown like: Ch. plumosus $>$ M. tuberculata $>$ T. tubifex.

The resistance of benthic hydrobionts to impact depends not only from the biological peculiarities of different species, but also from specific biotope, and composition of dredging material $[5,6,10-15]$.

\section{Acknowledgments}

The paper is prepared be the team of GET READY project (Getting Ready for the Cross-Border Challenges: Capacity Building in Sustainable Shore Use) financed by Russia, Finland and EU in the frames of the Cross-border Cooperation Programme «South-East Finland-Russia» aimed at support to education, research, technological development and innovation of the region. 


\section{References}

1. V. Badenko, N. Badenko, A. Nikonorov, D. Molodtsov, V. Terleev, Ju. Lednova, V. Maslikov, MATEC Web of Conferences, 73, 03003 (2016). DOI: 10.1051/matecconf/20167303003

2. A. Nikonorov, S. Pavlov, V. Terleev, N. Arefiev, V. Badenko, Yu. Volkova, Proc. Eng., 117, 258-263 (2015). DOI: 10.1016/j.proeng.2015.08.160

3. V. Abramov, I. Aleshin, V. Burlov, M. Shilin, A. Sokolov, Proceedings of the 33rd International Business Information Management Association Conference, IBIMA 2019: Education Excellence and Innovation Management through Vision 2020 (2019).

4. M. Shilin, T. Eremina, M. Mamaeva, A. Chusov, J. Lednova 12th International Conference on the Mediterranian Coastal Environment, MEDCOAST 2015, 1, 339-350 (2015).

5. A. Chusov, J. Lednova, M. Shilin, Ocean: Past, Present and Future - 2012 IEEE/OES Baltic International Symposium, BALTIC-2012 (2012). DOI: 10.1109/BALTIC.2012.6249169

6. M. Shilin, A. Ershova, V. Zhigulsky, A. Chusov, V. Abramov, T. Bagrova, N. Popov, 2018 IEEE/OES Baltic International Symposium, BALTIC 2018 (2018). DOI: 10.1109/BALTIC.2018.8634858

7. A.M. Kaskela, H. Rousib, G. Gogoberidze, M. Ronkainen, M. Orlova, A. Babine, K. Kostamo, A.T. Kotilainen, I. Neevin, D. Ryabchuk, A. Sergeev, V. Zhamoida, Continental Shelf Research, 142, 1-13 (2017). DOI: 10.1016/j.csr.2017.05.013.

8. M.J. Andrianova, K.V. Vorobjev, J.A. Lednova, A.N. Chusov, Appl. Mech. and Mat., 587-589, 653-656 (2014). DOI: 10.4028/www.scientific.net/AMM.587-589.653

9. A.A. Maximov, Russ. Jour. of Mar. Biol., 41 (4), 300-310 (2015). DOI: 10.1134/S1063074015040094

10. D. Ryabchuk, H. Vallius, V. Zhamoida, A.T. Kotilainen, A. Rybalko, N. Malysheva, N. Deryugina, L. Sukhacheva, Balt., 30 (1), 31-46 (2017). DOI: 10.5200/baltica.2017.30.04

11. R.N. Bray, Environmental aspects of dredging (IADC / CEDA, 2008). DOI: $10.1201 / 9780203894897$.

12. Ju. Lednova, A. Chusov, M. Shilin, EMRCS 2013 - MEDCOAST 2013 Joint conf., 2, 1024-1034 (2013).

13. A.A. Maximov, S.M. Golubkov, V.A. Petukhov, Inl. Wat. Biol., 7(4), 372-380 (2014). DOI: $10.1134 /$ S1995082914040099

14. E. Rumyantseva, G. Gogoberidze, V.M. Abramov, N. Rodin, G. Vladimirova, Proceedings of the International Multidisciplinary Scientific GeoConference Surveying Geology and Mining Ecology Management, SGEM, 17 (52), 921-927 (2017). DOI: $10.5593 /$ sgem 2017/52/S20.092

15. V. Burlov, V.M. Abramov, E. Istomin,,A. Fokicheva, A,Sokolov, Proceedings of the International Multidisciplinary Scientific GeoConference Surveying Geology and Mining Ecology Management, SGEM, 18 (2.2), 483-490 (2018). DOI: $10.5593 /$ sgem $2018 / 2.2 / \mathrm{S} 08.061$ 